\section{GLAUCOUS GULLS SIGHTED AT REGINA}

FRED W. LAHRMAN, Saskatchewan Museum of Natural History, Regina, Saskatchewan S4P 3V7.

The morning of 7 May 1979 saw a world of white. The ground was covered with approximately 5 inches of newly fallen snow. The sky was overcast and snow was still falling intermittently.

When I arrived at the lookout point by the grain bins near Goose Island I saw a huge white gull on the island. This gull, a second-year immature Glaucous Gull was being harassed by a number of Ring-billed, California and Herring gulls as it attempted to feed on a dead fish (Northern Pike). It picked up the fish and flew over a bank where it was out of sight.

Lorne Scott arrived a moment later with his camera, so we went over to the island hoping to get a picture. As we approached the gull, Lorne immediately spotted another, a gray first-year immature standing in the snow beside the first. They looked huge as they stood among the other gulls. Lorne took photos as they flew about and then they left. On 8 May Robert Kreba and I saw the white gull again as it flew about near Goose Island and then alighted near the Power House.

A number of Regina birders saw it, including $M$. Belcher, G. Seib and F. Brazier. Tom Riffle saw the 2 together again on Goose Island at noon. This was the first Regina record and at least the 12th Saskatchewan record. ${ }^{1234}$

'BELCHER, MARGARET. 1980. Birds of Regina. Sask. Natur. Hist. Soc. Spec. Publ. 12. $151 \mathrm{p}$.

${ }^{2}$ GOLLOP, J. B. 1979. Prairie Provinces region. Am. Birds 33(5):781-782.

${ }^{3}$ HARAS, WILLIE. 1978. Cold River Christmas Bird Count in M. I. Houston, 36th annual Christmas Bird Count 1977. Blue Jay 36(1):16-26.

${ }^{4} \mathrm{LEIGHTON}, \mathrm{F}$. A., and ANNA LEIGHTON. 1978. Glaucous Gull at Rosetown, Saskatchewan. Blue Jay 36(3):167. 